\title{
Differential Display Analysis of the Early Compatible Interaction Between Soybean and the Soybean Cyst Nematode
}

\author{
Dieter Hermsmeier, Mitra Mazarei, and Thomas J. Baum \\ Department of Plant Pathology, lowa State University, 351 Bessey Hall, Ames 50011, U.S.A. \\ Accepted 18 August 1998
}

\begin{abstract}
The marked cellular changes during feeding site formation of the soybean cyst nematode (Heterodera glycines) indicate major changes in soybean gene expression. We used differential display of mRNA to detect host gene expression changes during the early compatible interaction between soybean and $\boldsymbol{H}$. glycines. Fifteen cDNA clones corresponding to mRNAs with different abundances in $H$. glycines-infected versus uninfected roots were identified. Differential display results indicated that abundances of five mRNAs increased in infected roots, whereas abundances of $10 \mathrm{mRNAs}$ decreased. Transcripts for nine of these 15 cDNAs could be detected on RNA blots, and their hybridization signals confirmed the differential display results for eight of these nine cDNAs. Sequence analyses identified five cDNAs with decreased mRNA levels in infected roots as corresponding to two putative aldolase genes, a transcription-factor TFIIA homologue, the soybean small GTP-binding protein gene sra1, and the soybean auxin down-regulated gene ADR12. RNA blot analyses of other auxin down-regulated genes revealed a decrease in their mRNA abundances in $H$. glycinesinfected roots as well.
\end{abstract}

Additional keyword: syncytium.

The soybean cyst nematode (SCN), Heterodera glycines, is a sedentary endoparasite that causes severe yield losses in many soybean-producing countries (Wrather et al. 1997). In the U.S., SCN damage is regarded as the largest source of pathogen-related crop damage (Wrather and Sciumbato 1995; Wrather et al. 1995). In the north central U.S. alone, annual monetary losses exceeded hundreds of millions of dollars (Doupnik 1993). SCN management is complicated by economic constraints on farmers to maintain a high proportion of soybean plantings in crop rotations, thereby steadily increasing SCN field inoculum densities. Although available SCNresistant soybean cultivars decrease nematode reproduction they, nevertheless, experience substantial yield reductions (G.

Corresponding author: Thomas J. Baum; Telephone: 1-515-294-2398; Fax: 1-515-294-9420; E-mail: tbaum@iastate.edu

Present address of D. Hermsmeier: Max-Planck-Institut für Chemische Ökologie, Tatzendpromenade 1A, 07745 Jena, Germany.
L. Tylka, personal communication) and, more importantly, may become ineffective over time as virulent SCN populations are selected.

During the SCN life cycle, second-stage juveniles (J2) hatch from eggs in the soil and search for and invade soybean roots. Within the roots, they migrate intracellularly through the root cortex, probably relying on enzymatic softening of root tissues (Smant et al. 1998) and the piercing action of their protrusible mouth spears (stylets). J2 become sedentary when an initial feeding cell adjacent to host vascular tissues is selected and parasitized. The nematodes then induce cell morphology changes and symplastic fusion of adjacent root cells, leading to the formation of a syncytium. Sedentary nematodes feed from their syncytia and develop into adults.

The morphological and physiological changes of syncytium formation are thought to be the result of SCN-directed changes of soybean gene expression (reviewed by Williamson and Hussey 1996). This process is not understood. Several studies have shown the transcriptional regulation of gene expression in other cyst nematode pathosystems (Goddijn et al. 1993; Gurr et al. 1991; Hansen et al. 1996; Niebel et al. 1993, 1995, 1996; Strittmatter et al. 1996; Urwin et al. 1997). However, available data do not allow an understanding of cyst nematode-plant interactions. Identification and characterization of soybean genes that are potentially involved in the cyst nematode-plant interaction promise to be of high informative value.

Here we report on our efforts to identify genes that change their expression levels during the early stages of the compatible interaction between SCN and a susceptible soybean cultivar, through the use of differential display of mRNA (Liang and Pardee 1992). The performance of differential display increases dramatically with the quality of the selected starting material. Therefore, we devised two methods for the preparation of soybean tissues suitable for the analysis of gene expression changes (Fig. 1). While the inoculation method with whole soybean seedlings was used for the preparation of tissues for RNA blot experiments, the excised root tip method was chosen for the preparation of differential display starting materials, for the following reasons. The use of very short root pieces confined the invading nematodes to a small amount of tissue, resulting in an enrichment of host cells actually involved in the nematode-plant interaction. Furthermore, the use of cut root pieces for both the infected and the uninfected 
samples may have compensated for systemic plant wound responses due to SCN damage in infected roots. The advantages of both methods were the assurance of sterile starting material, defined developmental stages of root tissue and nematodes, synchronism of the infection process, and a confined infection zone, resulting in a relatively high proportion of host cells involved in interactions with SCN.

We used differential display to compare mRNA abundances in the following two treatments: (i) SCN-infected excised root tips $24 \mathrm{~h}$ after inoculation; and (ii) mock-inoculated, uninfected root tips to which an appropriate number of preparasitic nematodes had been added immediately before RNA extraction. Differential display analyses were adapted from the protocol of Liang et al. (1995). Briefly, the mRNA in $400 \mathrm{ng}$ of total cellular RNA was reverse transcribed with SuperscriptII $\mathrm{RNAseH}^{-}$reverse transcriptase (Life Technologies, Gaithersburg, $\mathrm{MD})$ and $1.25 \mu \mathrm{M}$ one discriminating anchor primer $\left(5^{\prime}\right.$ T12AC-3', 5'-T12AG-3', 5'-T12CA-3', 5'-T12CC-3', or 5'-
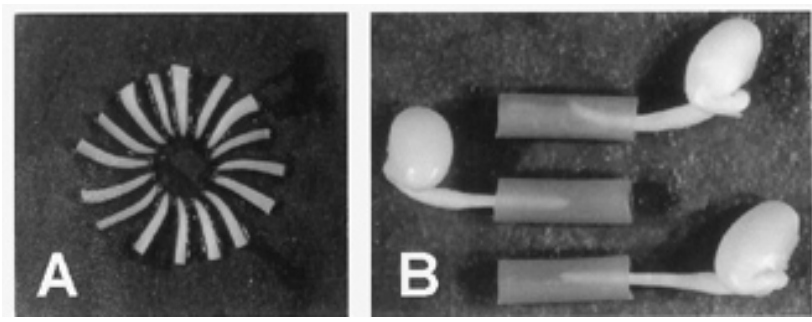

Fig. 1. Two methods for the inoculation of soybean primary roots with soybean cyst nematode second-stage juveniles. A, Inoculation of excised root tips. B, Inoculation of whole primary roots of 2-day-old soybean seedlings. For preparation of sterile soybean seedlings needed in both methods, seeds of susceptible cv. Corsoy 79 were surface sterilized by agitation for $3 \mathrm{~min}$ in $70 \%$ ethanol followed by $12 \mathrm{~min}$ in $0.525 \%$ sodium hypochlorite. Surface-sterilized seeds were allowed to germinate and grow for 2 days at $26^{\circ} \mathrm{C}$ in darkness on blue blotter paper circles (Anchor Paper, St. Paul, MN) soaked with a sterile aqueous $0.1 \mathrm{mg}$ of penicillin $\mathrm{G}$ per $\mathrm{ml}$ solution in plastic petri dishes. For the first method (A), root tips were cut to approximately 7-mm lengths from sterile 2day-old seedlings and transferred in groups of 16 onto blue blotter paper circles that had been placed in $60-\mathrm{mm}$ plastic petri dishes and wetted with Gamborg's B5 medium (Life Technologies, Gaithersburg, MD) containing $0.1 \mathrm{mg}$ of penicillin $\mathrm{G}$ per $\mathrm{ml}$. Inoculation was performed by pipetting $0.1 \mathrm{ml}$ of an agarose-nematode suspension, containing about 500 nematodes, into the center of each root circle. After solidifying, the agarose was covered with another $0.1 \mathrm{ml}$ of agarose without nematodes. In the second method $(\mathbf{B})$, primary roots of sterile 2-day-old seedlings were inoculated with nematodes by sliding a piece of sterile rubber tubing ( $2.5 \mathrm{~mm}$ inner diameter, $12 \mathrm{~mm}$ length) over the root tip and pipetting $0.1 \mathrm{ml}$ of the agarose suspension, containing approximately 200 nematodes, from the front opening into the tubing. Plates containing root tissues were sealed with Parafilm and incubated at $26^{\circ} \mathrm{C}$ in darkness. At $24 \mathrm{~h}$ post-inoculation, roots prepared by both methods were harvested, frozen in liquid nitrogen, and stored at $-80^{\circ} \mathrm{C}$ until used. Control roots underwent the same treatments except for receiving agarose without nematodes. For visual proof of infection, parasitic nematodes were stained in situ with acid fuchsin following the procedure of Hussey (1990). Throughout this study, the inbred line OP50 (Dong and Opperman 1997) of the soybean cyst nematode (Heterodera glycines) was used. Nematodes were propagated in greenhouse cultures with Corsoy 79 as host. Cysts and females were recovered from infected roots and eggs were released by standard nematological techniques. Nematodes were hatched in $3.14 \mathrm{mM} \mathrm{ZnSO}_{4}$ on modified Baerman pans. Nematodes were surface sterilized for $12 \mathrm{~min}$ in $0.01 \%$ mercuric chloride and subsequently washed 3 times in sterile $10 \mathrm{mM}$ potassium phosphate buffer, $\mathrm{pH}$ 7.0. After the final wash, the nematodes were pelleted by centrifugation for $1 \mathrm{~min}$ at $10,000 \times \mathrm{g}$ and resuspended in $1.5 \%$ lowmelting point agarose (Life Technologies) at $37^{\circ} \mathrm{C}$.
T12CG-3') in $20 \mu \mathrm{l}$ of total volume. A $20-\mu 1$ differential display polymerase chain reaction (PCR) contained $2 \mu$ of the reverse transcription reaction, $1.25 \mu \mathrm{M}$ respective anchor primer, $0.25 \mu \mathrm{M}$ arbitrary 10 -mer primer (5'GGTACTAAGG-3' [R6] or 5'-GATCACGTAC-3' [R8]), 1.5 $\mathrm{mM} \mathrm{MgCl}_{2}, 2 \mu \mathrm{M}$ (each) dATP, dCTP, dGTP, and dTTP, 10 $\mu \mathrm{Ci}$ of $\alpha^{33} \mathrm{P}-\mathrm{dCTP}$, and 1 unit Taq DNA polymerase (Life Technologies, Gaithersburg, MD) in $1 \times$ Taq DNA polymerase PCR buffer. Each reaction contained 220 ng of TaqStart antibody (Clontech Laboratories, Palo Alto, CA) in order to allow a hot-start PCR. For temperature cycling the following program was used: 1 cycle $2 \mathrm{~min}$ at $94^{\circ} \mathrm{C} ; 40$ cycles $(30 \mathrm{~s}$ at $94^{\circ} \mathrm{C}, 2 \mathrm{~min}$ at $40^{\circ} \mathrm{C}, 30 \mathrm{~s}$ at $72^{\circ} \mathrm{C}$ ); 1 cycle $5 \mathrm{~min}$ at $72^{\circ} \mathrm{C}$; hold at $4^{\circ} \mathrm{C}$. PCR products were separated on denaturing sequencing gels (Sambrook et al. 1989) containing 6\% vol/vol LongRanger gel solution (FMC BioProducts, Rockland, ME). Gels were dried, and autoradiography was performed. Film images were surveyed for treatment-specific or treatmentpreferential signals. All differential display reactions were performed in duplicate. Interesting bands were excised from the gels. Excised gel bands containing cDNAs of interest were transferred into $0.1 \mathrm{ml}$ of distilled water and incubated for 10 $\mathrm{min}$ at room temperature followed by $15 \mathrm{~min}$ of incubation at $100^{\circ} \mathrm{C}$ in order to elute the cDNAs. Reamplification of cDNAs was carried out in a $40-\mu 1$ PCR (identical program as above) containing $2 \mu \mathrm{l}$ of cDNA eluate, $0.5 \mu \mathrm{M}$ anchor primer, $0.5 \mu \mathrm{M}$ arbitrary primer, $1.5 \mathrm{mM} \mathrm{MgCl}_{2}, 20 \mu \mathrm{M}$ each dATP, dCTP, dGTP, and dTTP, 440 ng of TaqStart antibody, and 2 units of Taq DNA polymerase (Life Technologies) in 1× Taq DNA polymerase PCR buffer.

Reamplified cDNAs were ligated into the pGEM-T Easy vector (Promega, Madison, WI) following the manufacturer's protocol and transformed into Escherichia coli XLI-Blue MRF' cells (Stratagene, La Jolla, CA). For each candidate cDNA, six transformant colonies were cultured and their plasmids isolated. Of each plasmid, $200 \mathrm{ng}$ was slot blotted in duplicate with a Hoefer PR 648 slot blot filtration manifold (Amersham Pharmacia Biotech, Piscataway, NJ) according to the manufacturer's guidelines. Duplicate slot blots of the six plasmids of each transformation were probed with the appropriate differential display reaction mix derived from RNA from either uninfected or infected roots (Vögeli-Lange et al.

Table 1. Designation, polymerase chain reaction primers, length, and accession number for all cDNA clones identified through differential display analyses of soybean cyst nematode-infected and uninfected soybean roots

\begin{tabular}{lccc}
\hline Clone & Primers & Length & Accession no. \\
\hline $\mathrm{D} 8.3$ & $\mathrm{~T}_{12} \mathrm{CG} / \mathrm{R} 6$ & $163 \mathrm{bp}$ & AF068120 \\
$\mathrm{D} 10.1$ & $\mathrm{~T}_{12} \mathrm{CG}$ & $580 \mathrm{bp}$ & AF068121 \\
$\mathrm{D} 11.5$ & $\mathrm{~T}_{12} \mathrm{CG} / \mathrm{R} 8$ & $393 \mathrm{bp}$ & AF068122 \\
$\mathrm{D} 12.4$ & $\mathrm{~T}_{12} \mathrm{CG} / \mathrm{R} 8$ & $259 \mathrm{bp}$ & AF068123 \\
$\mathrm{D} 13.4$ & $\mathrm{~T}_{12} \mathrm{CG} / \mathrm{R} 8$ & $215 \mathrm{bp}$ & AF068124 \\
D14.4 & $\mathrm{T}_{12} \mathrm{CG} / \mathrm{R} 8$ & $162 \mathrm{bp}$ & AF068125 \\
$\mathrm{D} 17.1$ & $\mathrm{~T}_{12} \mathrm{AG} / \mathrm{R} 6$ & $326 \mathrm{bp}$ & AF068126 \\
$\mathrm{D} 19.4$ & $\mathrm{~T}_{12} \mathrm{CA} / \mathrm{R} 6$ & $318 \mathrm{bp}$ & AF068127 \\
$\mathrm{D} 20.1$ & $\mathrm{~T}_{12} \mathrm{CC}$ & $265 \mathrm{bp}$ & AF068128 \\
$\mathrm{D} 21.4$ & $\mathrm{~T}_{12} \mathrm{AC} / \mathrm{R} 8$ & $550 \mathrm{bp}$ & AF068129 \\
$\mathrm{D} 22.2$ & $\mathrm{~T}_{12} \mathrm{AC} / \mathrm{R} 8$ & $465 \mathrm{bp}$ & AF068130 \\
$\mathrm{D} 23.6$ & $\mathrm{~T}_{12} \mathrm{AG} / \mathrm{R} 8$ & $230 \mathrm{bp}$ & AF068131 \\
$\mathrm{D} 24.5$ & $\mathrm{~T}_{12} \mathrm{AG} / \mathrm{R} 8$ & $185 \mathrm{bp}$ & AF068132 \\
$\mathrm{D} 25.1$ & $\mathrm{~T}_{12} \mathrm{CA} / \mathrm{R} 8$ & $297 \mathrm{bp}$ & AF068133 \\
$\mathrm{D} 26.6$ & $\mathrm{~T}_{12} \mathrm{CA} / \mathrm{R} 8$ & $168 \mathrm{bp}$ & AF068134 \\
\hline
\end{tabular}


1996). Hybridized probes were quantified with a Storm 840 PhosphorImager and ImageQuant software (both from Molecular Dynamics, Sunnyvale, CA). Clones that exhibited the predicted hybridization intensity differences were retained for further analyses. This method allowed the identification of plasmids containing the PCR product corresponding to the polymorphic band originally detected in the differential display gel.

With 10 primer combinations, 26 differential display bands with intensity differences between the two differential display treatments were identified. Of the 26,15 were recovered as plasmid clones that showed hybridization intensity differences

Table 2. Basic local alignment search tool (BLAST) search results and mRNA abundance changes for the cDNA clones identified by differential display analyses

\begin{tabular}{|c|c|c|c|c|c|c|}
\hline \multirow[b]{2}{*}{ Clone } & \multicolumn{3}{|l|}{ BLAST search results } & \multicolumn{3}{|c|}{$\begin{array}{l}\text { Transcript change in } \\
\text { infected roots }(\%)^{\mathrm{a}}\end{array}$} \\
\hline & Sequence similarities, accession nos., and references & Score & $\boldsymbol{P}$ & $\begin{array}{l}\text { Slot } \\
\text { blot }^{\mathbf{b}}\end{array}$ & $\begin{array}{l}\text { Total } \\
\text { RNA blot }\end{array}$ & $\begin{array}{l}\text { Poly(A) } \\
\text { RNA blot }^{\mathrm{d}}\end{array}$ \\
\hline D8.3 & No significant similarity & - & - & -39 & ND & NP \\
\hline D10.1 & Arabidopsis thaliana BAC F5J6 (AC002329) & 220 & $3.9 \times 10^{-16}$ & +59 & +24 & NP \\
\hline D11.5 & Arabidopsis thaliana large subunit of transcription factor TFIIA (X98861) & 346 & $1.1 \times 10^{-18}$ & -40 & NP & -57 \\
\hline D12.4 & No significant similarity & - & - & +106 & ND & NP \\
\hline D13.4 & Glycine max auxin-down regulated gene ADR12 (X69641; Datta et al. 1993) & 636 & $1.0 \times 10^{-72}$ & -52 & NP & -66 \\
\hline D14.4 & No significant similarity & - & - & -20 & ND & NP \\
\hline D17.1 & No significant similarity & - & - & +37 & +4 & NP \\
\hline D19.4 & No significant similarity & - & - & -60 & -8 & NP \\
\hline D20.1 & No significant similarity & - & - & -38 & ND & NP \\
\hline D21.4 & Rattus norvegicus Aldolase A (X04264; Joh et al. 1986) & 147 & $4.2 \times 10^{-2}$ & -46 & -16 & -42 \\
\hline $\mathrm{D} 22.2$ & Glycine max small GTP-binding protein sral (U58853; Yamagata et al. 1997) & 2080 & $5.0 \times 10^{-168}$ & -35 & $\mathrm{NP}$ & -27 \\
\hline D23.6 & Arabidopsis thaliana BAC F1N21 (AC002130) & 162 & $1.7 \times 10^{-3}$ & +200 & ND & NP \\
\hline D24.5 & No significant similarity & - & - & +180 & ND & NP \\
\hline $\mathrm{D} 25.1$ & Rattus norvegicus Aldolase A (X04264; Joh et al. 1986) & 147 & $4.2 \times 10^{-2}$ & -33 & -6 & -56 \\
\hline D26.6 & $\begin{array}{l}\text { Homo sapiens HXC-26 (D83260; Toyoda et al. 1996); XAP-5 (AD001530; } \\
\text { Mazzarella et al. 1997); 9F (X87199; Bione et al. 1993) }\end{array}$ & 175 & $5.6 \times 10^{-5}$ & -55 & 0 & $\mathrm{NP}$ \\
\hline
\end{tabular}

${ }^{a}$ Values were calculated by determining the difference between hybridization signals for infected and uninfected roots and expressing this difference as percent hybridization signal obtained for uninfected roots. Hybridization signals were quantified with a phosphorimager. ND $=$ hybridizations that did not yield detectable signals; $\mathrm{NP}=$ experiments that were not performed.

${ }^{\mathrm{b}}$ Slot blot values were obtained by probing duplicate slot blots of cDNA clones derived from differential display gels with the respective differential display reaction mixes as described in the text.

${ }^{c}$ See Figure 3 for images.

${ }^{\mathrm{d}}$ See Figure 4 for images.

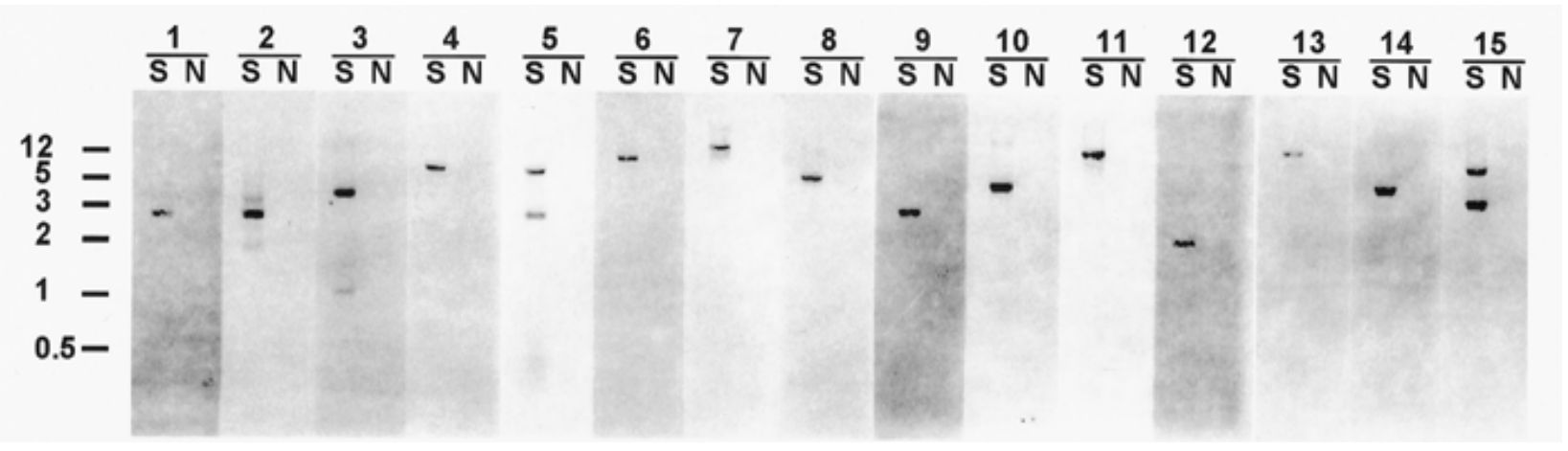

Fig. 2. Blots of EcoRI-digested genomic DNA (10 $\mu \mathrm{g}$ per lane) of soybean (S) and soybean cyst nematode (N) hybridized at high stringency with D8.3 (1), D10.1 (2), D11.5 (3), D12.4 (4), D13.4 (5), D14.4 (6), D17.1 (7), D19.4 (8), D20.1 (9), D21.4 (10), D22.2 (11), D23.6 (12), D24.5 (13), D25.1 (14), and D26.6 (15). Size markers (M) are given in kilobase pairs. High-molecular-weight genomic DNA was prepared from frozen tissue ground under liquid nitrogen. Extraction was performed by adding $10 \mathrm{ml}$ of phenol reagent (Tris EDTA [TE]-saturated phenol pH 8.0, 0.1\% wt/vol 8-hydroxyquinoline) and $10 \mathrm{ml}$ of extraction buffer $(0.1 \mathrm{M} \mathrm{LiCl}, 0.1 \mathrm{M}$ Tris/Cl pH 9.0, $10 \mathrm{mM}$ EDTA, $1 \% \mathrm{wt} /$ vol sodium dodecyl sulfate [SDS]). After gentle shaking for 30 min, phases were separated by centrifugation for $5 \mathrm{~min}$ at $3,000 \times \mathrm{g}$. The aqueous phase was extracted one more time with $10 \mathrm{ml}$ of phenol reagent and, subsequently, two times with $10 \mathrm{ml}$ of chloroform. RNA was removed by $\mathrm{LiCl}$ precipitation according to Pelham (1985). The resulting genomic DNA was isopropanol-precipitated, washed in 70\% ethanol, and redissolved in TE buffer. Residual RNA contaminations were removed by adding 200 mg of DNAse-free RNAse A (Sigma, St. Louis, MO) per ml and incubating for $30 \mathrm{~min}$ at $37^{\circ} \mathrm{C}$. Hybridizations were carried out at $42^{\circ} \mathrm{C}$ in a hybridization buffer composed of $5 \times$ SSPE ( $1 \times$ SSPE is $0.15 \mathrm{M} \mathrm{NaCl}, 10 \mathrm{mM} \mathrm{NaPO}_{4}$, and $1 \mathrm{mM}$ EDTA [pH 7.4]), 50\% formamide, $0.1 \%$ SDS, $5 \times$ Denhardt's solution, $0.1 \mathrm{mg}$ of herring-sperm DNA per $\mathrm{ml}$, and $3 \times 10^{6} \mathrm{cpm} / \mathrm{ml}$ of labeled gene probe. Inserts in the pGEM-T Easy vector (Promega, Madison, WI) were labeled via polymerase chain reaction with $0.5 \mu \mathrm{M}$ (each) vector-specific primers pgem-up (5'-ATGGCGGCCGCGGGAATTCG-3') and pgem-dwn (5'GCAGGCGGCCGCGAATTCAC-3'). All hybridized blots were washed twice for $20 \mathrm{~min}$ in $0.1 \% \mathrm{SDS} / 0.1 \times \mathrm{SSC}(1 \times \mathrm{SSC}$ is $0.15 \mathrm{M} \mathrm{NaCl}$, and $15 \mathrm{mM}$ sodium citrate, $\mathrm{pH} 7.0)$ at $68^{\circ} \mathrm{C}$. Bound radiolabeled probes were visualized by standard autoradiography methods. 
in the above-described slot blot assay (Tables 1 and 2). When compared with uninfected roots, five cDNAs corresponded to mRNAs with increased abundance in infected roots and 10 cDNAs corresponded to mRNAs with decreased mRNA abundance in infected roots.

High-stringency hybridizations of blots of EcoRI-digested genomic DNA from soybean and SCN revealed that all 15 cDNAs originated from soybean (Fig. 2). Nucleotide sequencing revealed that 13 of the 15 recovered differential diplay clones carried the expected primers at their ends, while the remaining two clones (D10.1 and D20.1) were terminated by the respective anchor primer on both ends (Table 1). The sequences of all clones were subjected to data base comparisons with the BLAST algorithm (Altschul et al. 1990; Table 2). Seven clones (D8.3, D12.4, D14.4, D17.1, D19.4, D20.1, and D24.5) showed no convincing sequence similarities. Weak similarities were observed with an Arabidopsis thaliana genomic sequence (D23.6) and a rat aldolase A gene (D21.4 and D25.1). Clone D26.6 showed strong similarity to three human mRNAs: HXC-26 (Toyoda et al. 1996); XAP-5 (Mazzarella et al. 1997); and 9F (Bione et al. 1993). Two other cDNAs showed convincing similarities to a genomic $A$. thaliana sequence (D10.1) and to the large subunit of the $A$. thaliana transcription factor TFIIA (D11.5). Clone D13.4 was identical to the soybean auxin down-regulated gene ADR12 (Datta et al. 1993), and clone D22.2 was identical to the soybean small GTP-binding protein gene sral (Yamagata et al. 1997).

Radiolabeled DNA probes of 12 of the identified cDNA clones (D8.3, D10.1, D12.4, D14.4, D17.1, D19.4, D20.1, $\mathrm{D} 21.4, \mathrm{D} 23.6, \mathrm{D} 24.5, \mathrm{D} 25.1$, and D.26.6) were used to probe blots prepared from total RNA extracted from SCNinfected and uninfected excised soybean root tips. Six clones (D10.1, D17.1, D19.4, D21.4, D25.1, and D26.6) produced detectable signals on autoradiographs after 15 days of exposure (Fig. 3; Table 2). The obtained hybridization signals for five of the detectable six probes confirmed the mRNA level differences predicted by the differential display analyses although the observed intensity differences were small. However, additional probing of poly(A)enriched RNA blots with D21.4 and D25.1 (see below) and of total RNA blots of later time points with D10.1 and D17.1 (data not shown) produced much more pronounced differences. One clone (D26.6) did not reveal obvious differences in transcript abundance.

Equal loading of total RNA blots was confirmed by visual assessment of the ribosomal RNA bands in the agarose gel. Additionally, one blot was probed with a soybean rRNA gene fragment (Eckenrode et al. 1984) and a soybean actin 3 gene fragment (Nagao et al. 1981). These hybridizations revealed that in our experiments actin 3 mRNA abundances were unchanged when infected and uninfected roots were compared $24 \mathrm{~h}$ after inoculation (Fig. 3). The actin 3 hybridization probe was subsequently used to normalize blots of poly(A)-enriched RNA (see below).

Pooled poly(A)-enriched RNA obtained from two independent inoculations of primary roots and excised root tips (Fig. 1) was blotted and probed with riboprobes derived from D11.5, D13.4, D21.4, D22.2, and D25.1. All probes produced hybridization signals that supported the differential display results (Fig. 4 [D21.4 not shown]; Table 2). Because clone D13.4 was identical to the auxin down-regulated gene

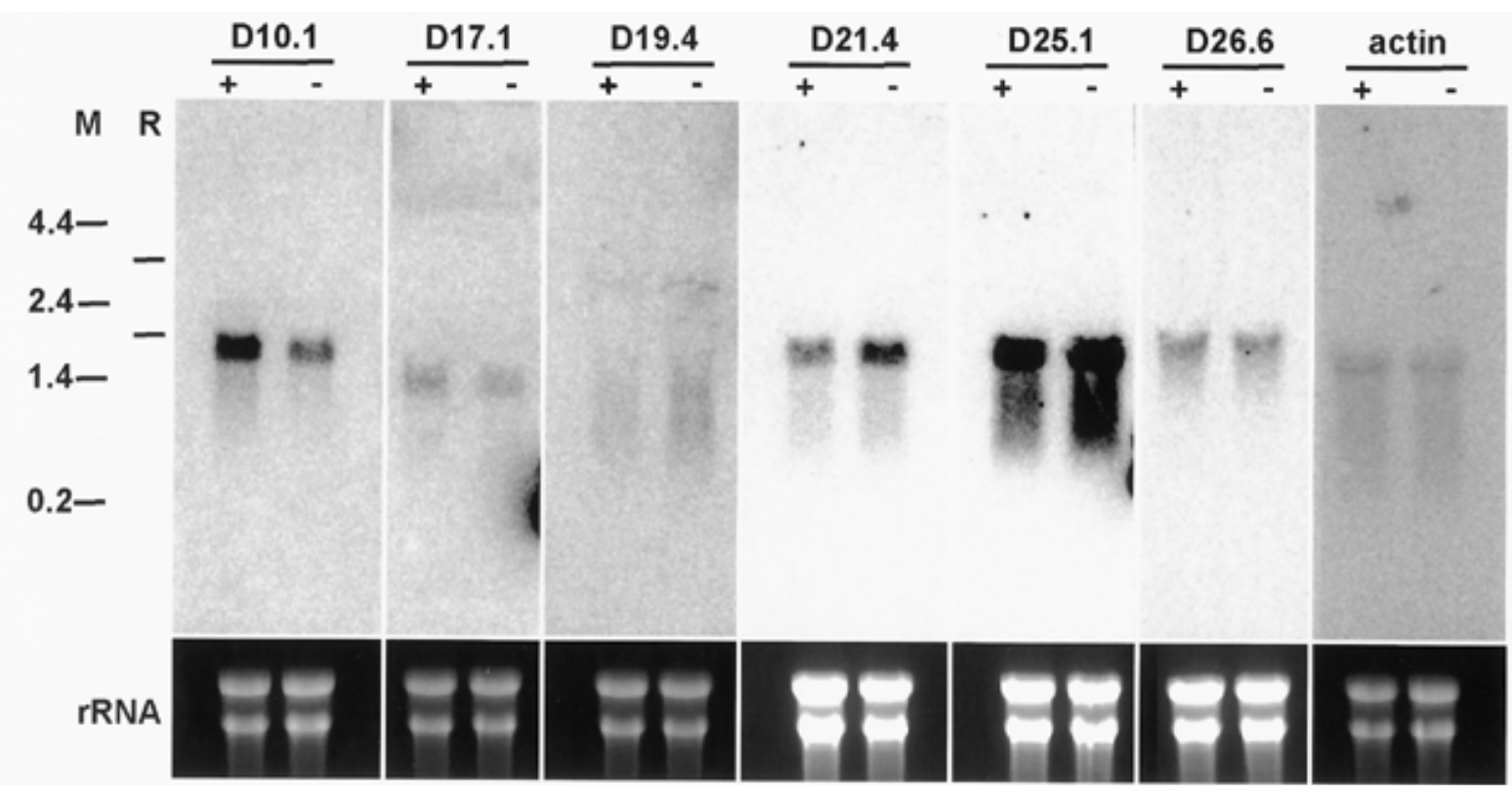

Fig. 3. Blots of total RNA extracted from soybean cyst nematode-infected (+) and uninfected (-) excised soybean root tips $24 \mathrm{~h}$ after inoculation. Blots were exposed for 15 days. Size markers are given in kilobases (M) and positions of 28S and 18S rRNA bands are indicated (R). Lower panel (rRNA) shows ethidium bromide-stained agarose gel before blotting. Each lane contained $10 \mu \mathrm{g}$ of RNA and apparently different staining intensities are due to varying exposure times during photography of the agarose gels. Isolation of total RNA was performed as described in Pawlowski et al. (1994). Probes for the soybean actin 3 (Nagao et al. 1981) and rRNA (Eckenrode et al. 1984) clones were radiolabeled by random priming (Random Primers DNA Labeling System; Life Technologies, Gaithersburg, MD) of gel-purified cDNA fragments. Other probes were prepared and all blots were hybridized and washed as described in Figure 2. Bound radiolabeled probes were visualized by standard autoradiography methods with a Storm840 PhosphorImager, which allowed exact quantification of hybridized probe with the ImageQuant software (both from Molecular Dynamics, Sunnyvale, CA). 
ADR12, partial cDNAs of the auxin down-regulated genes ADR6 and ADR11 (Baulcombe and Key 1980) were used as riboprobes on identical poly(A)-enriched RNA blots. All three auxin down-regulated genes (ADR 6, 11, and 12) showed strong mRNA decreases upon nematode infection of $-80,-64$, and $-66 \%$, respectively. These conspicuous decreases in mRNA abundances suggest increased auxin concentration or sensitivity in SCN-infected roots. Similar conclusions can be drawn from the observed activation of auxin-responsive promoters in potato roots infected by the potato cyst nematode, Globodera rostochiensis (Goverse et al. 1998).

Results from RNA blot analyses confirmed the differential display results for eight of the nine mRNAs above the detection limit. We, therefore, conclude that differential display in combination with the described slot blot screening procedure provided a reliable tool to detect mRNA abundance differences. The actual percentage of transcript changes determined by slot blot hybridizations versus RNA blots was, not surprisingly, different. This result was most likely due to disproportionate amplification of cDNAs during the differential display PCR reactions. Furthermore, the actual RNA preparations used for differential display reactions and RNA blots were from different root inoculations, so that different results for the individual assays could be expected. The fact that for several cDNAs the observed expression changes were evident in separate RNA preparations lends veracity to our findings.

A high degree of complexity of the SCN-soybean interac- tion has to be assumed, since the use of only 10 different primer combinations for the differential display experiments identified 15 soybean genes that appeared to change their transcription during SCN infection. Further analysis of the isolated cDNA fragments has the potential to reveal gene functions and, therefore, to enhance our understanding of the compatible interaction between soybean and SCN.

\section{ACKNOWLEDGMENTS}

Journal paper no. J-17960 of the Iowa Agriculture and Home Economics Experiment Station, Ames, IA, project no. 3381, and supported by Hatch Act and State of Iowa funds. We gratefully acknowledge funding by the Iowa Soybean Promotion Board and the Iowa State University Biotechnology Council. We thank R. Nagao for kindly providing clones for ADR6 and ADR11. We also thank T. R. Maier for skillful technical assistance and C. R. Bronson, J. M. de Boer, and G. L. Tylka for critical review of the manuscript.

\section{LITERATURE CITED}

Altschul, S. F., Gish, W., Miller, W., Myers, E. W., and Lipman, D. J. 1990. Basic local alignment search tool. J. Mol. Biol. 215:403-410.

Baulcombe, D. C., and Key, J. L. 1980. Polyadenylated RNA sequences which are reduced in concentration following auxin treatment of soybean hypocotyls. J. Biol. Chem. 255:8907-8913.

Bione, S., Tamanini, F., Maestrini, E., Tribioli, C., Poustka, A., Torri, G., Rivella, S., and Tonioli, D. 1993. Transcriptional organization of a $450-\mathrm{kb}$ region of the human $\mathrm{X}$ chromosome in Xq28. Proc. Natl.

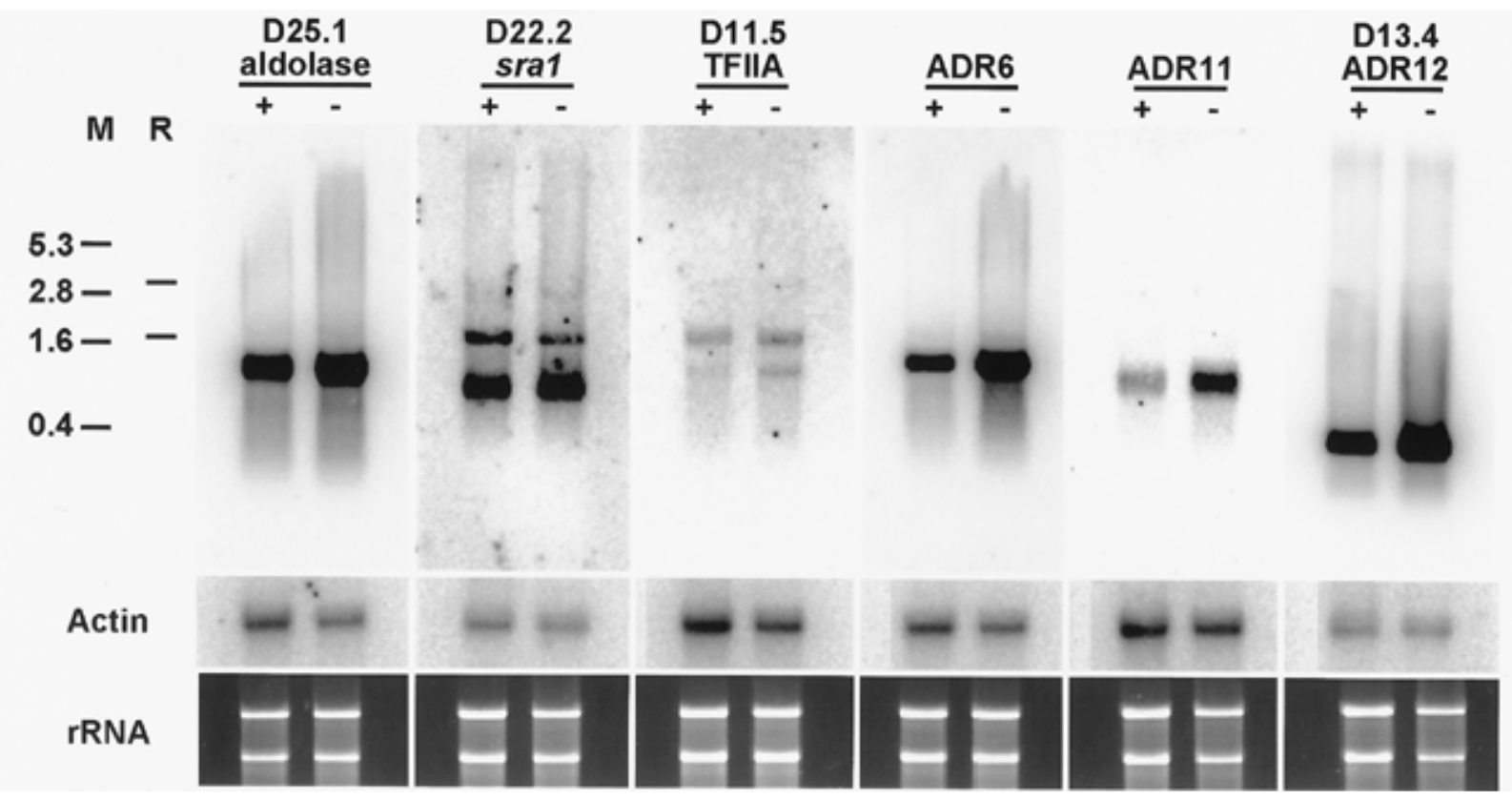

Fig, 4. Blots of poly(A)-enriched RNA ( $5 \mu \mathrm{g}$ per lane) derived from soybean cyst nematode-infected (+) and uninfected (-) soybean root tissues $24 \mathrm{~h}$ after inoculation. Blots were hybridized with riboprobes. Blots probed with D25.1, ADR6, and D13.4 were exposed for 40 h; blots probed with D22.2, D11.5, and ADR11 were exposed for $300 \mathrm{~h}$. Positions of RNA size standards in kilobases (M) and positions of 28S and 18S rRNAs (R) are indicated. Lower panels show hybridization signals obtained with actin 3 probe (Actin) and ethidium bromide-stained agarose gel before blotting (rRNA). Poly(A) RNA was isolated from total RNA with the MPG mRNA purification kit (CPG, Lincoln Park, NJ) according to the manufacturer's recommendations. To generate riboprobes, transcription vector pBS-T was constructed by removing the GC-rich multicloning cassette of the plasmid pBluescriptII (Stratagene, La Jolla, CA) by excision with KpnI (Life Technologies, Gaithersburg, MD) and SacI (New England Biolabs, Beverly, MA). Removed sequence was replaced with an adapter carrying KpnI and SacI ends and internal cloning sites EcoRI, SmaI, and BamHI. Adapter was generated by annealing oligonucleotides 5'-CGAATTCCCGGGATCCGAGCT-3' and 5'-CGGATCCCGGGAATTCGGTAC-3'. After cDNAs were cloned into the BamHI site, the transcription cassette including T7 and T3 promoters was excised with BssHII (New England Biolabs) and gel-purified with a gel-extraction kit (Qiagen, Chatsworth, CA). The purified cassette then served as template for riboprobe transcription. Blots were hybridized and washed as described in Figure 2; bound radiolabeled probes were detected as described in Figure 3. 
Acad. Sci. USA 90:10977-10981.

Datta, N., LaFayette, P. R., Kroner, P. A., Nagao, R. T., and Key, J. L. 1993. Isolation and characterization of three families of auxin downregulated cDNA clones. Plant Mol. Biol. 21:859-869.

Dong, K., and Opperman, C. H. 1997. Genetic analysis of parasitism in the soybean cyst nematode Heterodera glycines. Genetics 146:13111318

Doupnik, B., Jr. 1993. Soybean production and disease loss estimates for North Central United States from 1989 to 1991. Plant Dis. 77:11701171

Eckenrode, V. K., Arnold, J., and Meagher, R. B. 1984. Comparison of the nucleotide sequence of soybean $18 \mathrm{~S}$ rRNA with the sequences of other small-subunit rRNAs. J. Mol. Evol. 21:259-269.

Goddijn, O. J. M, Lindsey, K., van der Lee, F. M., Klap, J. C., and Sijmons, P. C. 1993. Differential gene expression in nematode-induced feeding structures of transgenic plants harbouring promoter-gusA fusion constructs. Plant J. 4:863-873.

Goverse, A., Biesheuvel, J., Wijers, G.-J., Gommers, F. J., Bakker, J., Schots, A., and Helder, J. 1998. In planta monitoring of the activity of two constitutive promoters, CaMV $35 \mathrm{~S}$ and TR2', in developing feeding cells induced by Globodera rostochiensis using green fluorescent protein in combination with confocal laser scanning microscopy. Physiol. Mol. Plant Pathol. 52:275-284.

Gurr, S. J., McPherson, M. J., Scollan, C., Atkinson, H. J., and Bowles, D. J. 1991. Gene expression in nematode-infected plant roots. Mol. Gen. Genet. 226:361-366.

Hansen, E., Harper, G., McPherson, M. J., and Atkinson, H. J. 1996 Differential expression patterns of the wound-inducible transgene wun1-uidA in potato roots following infection with either cyst or root knot nematodes. Physiol. Mol. Plant Pathol. 48:161-170.

Hussey, R. 1990. Staining nematodes in plant tissue. Pages 190-193 in: Plant Nematology Laboratory Manual. B. M. Zuckerman, W. F. Mai, and L. R. Krusberg, eds. Univ. Mass. Agric. Exp. Sta., Amherst.

Joh, K., Arai, Y., Mukai, T., and Hori, K. 1986. Expression of three mRNA species from a single rat aldolase A gene, differing in their $5^{\prime}$ non-coding regions. J. Mol. Biol. 190:401-410.

Liang, P., Bauer, D., Averboukh, L., Warthoe, P., Rohrwild, M., Müller, H., Strauss, M., and Pardee, A. B. 1995. Analysis of altered gene expression by differential display. Methods Enzymol. 254:304-321.

Liang, P., and Pardee, A. B. 1992. Differential display of eukaryotic messenger RNA by means of the polymerase chain reaction. Science 257:967-971

Mazzarella, R., Pengue, G., Yoon, J., Jones, J., and Schlessinger, D. 1997. Differential expression of XAP5, a candidate disease gene. Genomics 45:216-219.

Nagao, R. T., Shah, D. M., Eckenrode, V. K., and Meagher, R. B. 1981. Multigene family of Actin-related sequences isolated from a soybean genomic library. DNA 2:1-9.

Niebel, A., De Almeida Engler, J., Hemerly, A., Ferreira, P., Inzé, D., Van Montagu, M., and Gheysen, G. 1996. Induction of $c d c 2 a$ and cyclAt expression in Arabidopsis thaliana during early phases of nematode-induced feeding cell formation. Plant J. 10:1037-1043.

Niebel, A., De Almeida Engler, J., Tiré, C., Engler, G., Van Montagu,
M., and Gheysen, G. 1993. Induction patterns of an extensin gene in tobacco upon nematode infection. Plant Cell 5:1697-1710.

Niebel, A., Heungens, K., Barthels, N., Inzé, D., Van Montagu, M., and Gheysen, G. 1995. Characterization of a pathogen-induced potato catalase and its systemic expression upon nematode and bacterial infection. Mol. Plant-Microbe Interact. 8:371-378.

Pawlowski, K., Kunze, R., De Vries, S., and Bisseling, T. 1994. Isolation of total, poly(A) and polysomal RNA from plant tissues. Pages D5/1D5/4 in: Plant Molecular Biology Manual. S. B. Gelvin and R. A. Schilperoort, eds. Kluwer Academic, Dordrecht, The Netherlands.

Pelham, H. 1985. Cleaning up plasmid minipreps with lithium chloride. Trends Genet. 1:6.

Sambrook, J., Fritsch, E. F., and Maniatis, T. A. 1989. Molecular Cloning: A Laboratory Manual. 2nd ed. Cold Spring Harbor Laboratory, Cold Spring Harbor, NY.

Smant, G., Stokkermans, J. P. W. G., Yan, Y., de Boer, J. M., Baum, T. J., Wang, X., Hussey, R. S., Gommers, F. J., Henrissat, B., Davis, E. L., Helder, J., Schots, A., and Bakker, J. 1998. Endogenous cellulases in animals: Isolation of $\beta-1,4-e n d o g l u c a n a s e$ genes from two species of plant-parasitic cyst nematodes. Proc. Natl. Acad. Sci. USA 95:49064911.

Strittmatter, G., Gheysen, G., Gianinazzi-Pearson, V., Hahn, K., Niebel, A., Rohde, W., and Tacke, E. 1996. Infections with various types of organisms stimulate transcription from a short promoter fragment of the potato gstl gene. Mol. Plant-Microbe Interact. 9:68-73.

Toyoda, A., Sakai, T., Sugiyama, Y., Kusuda, J., Hashimoto, K., and Maeda, H. 1996. Isolation and analysis of a novel gene, HXC-26, adjacent to the $r a b$ GDP dissociation inhibitor gene located at human chromosome Xq28 region. DNA Res. 3:337-340.

Urwin, P. E., Møller, S. G., Lilley, C. J., McPherson, M. J., and Atkinson, H. J. 1997. Continual green-fluorescent protein monitoring of cauliflower mosaic virus $35 \mathrm{~S}$ promoter activity in nematode-induced feeding cells in Arabidopsis thaliana. Mol. Plant-Microbe Interact. 10:394-400.

Vögeli-Lange, R., Brückert, N., Boller, T., and Wiemken, A. 1996. Rapid selection and classification of positive clones generated by mRNA differential display. Nucleic Acids Res. 24:1385-1386.

Williamson, V. M., and Hussey, R. S. 1996. Nematode pathogenesis and resistance in plants. Plant Cell 8:1735-1745.

Wrather, J. A., Anderson, T. R., Arsyad, D. M., Gai, J., Ploper, L. D., Porta-Puglia, A., Ram, H. H., and Yorinori, J. T. 1997. Soybean disease loss estimates for the top 10 soybean producing countries in 1994. Plant Dis. 81:107-110.

Wrather, J. A., Chambers, A. Y., Fox, J. A., Moore, W. F., and Sciumbato, G. L. 1995. Soybean disease loss estimates for the southern United States, 1974 to 1994. Plant Dis. 79:1076-1079.

Wrather, J. A., and Sciumbato, G. L. 1995. Soybean disease loss estimates for the southern United States during 1992 and 1993. Plant Dis. 79:84-85

Yamagata, H., Harada, F., Bowler, C., Teruo, I. and Aizono, Y. 1997. Molecular cloning of two cDNAs encoding small GTP-binding proteins from dark-adapted soybean suspension-cultured cells. Plant Physiol. 115:1730 (Plant Gene Register). 